\title{
PENINGKATAN HASIL BELAJAR KOGNITIF MENGGUNAKAN STRATEGI PEMBELAJARAN PROBLEM BASED LEARNING (PBL) PADA PEMBELAJARAN BIOLOGI DI KABUPATEN DELI SERDANG
}

\author{
Anggi Tias Pratama (gietyas@gmail.com) \\ Universitas Muslim Nusantara Al Washliyah Medan
}

\begin{abstract}
ABSTRAK
Hasil belajar kognitif merupakan salah satu keterampilan yang dibutuhkan dalam suatu pembelajaran di Abad ke 21 dalam pembelajaran Biologi. Pemberdayaan keterampilan berpikir dan metakognitif perlu dilakukan agar peserta didik menjadipebelajar mandiri. Strategi PBL ini dalam pembelajaran diharapkan dapat membantu siswa untuk meningkatkan kemampuan hasil belajar kognitif siswa dalam pembelajaran Biologi. Penelitian ini bertujuan untuk mengetahui peningkatan hasil belajar kognitif siswa yang diajar dengan strategi PBL. Hasil penelitian menunjukkan bahwa strategi PBL dapat meningkatkan hasil belajar kognitif siswa pada kemampuan berbeda. Peningkatan Hasil Belajar Kognitif siswa pada strategi PBL sebesar $65.52 \%$ dan konvensional sebesar $53.41 \%$.
\end{abstract}

Kata Kunci: Problem Based Learning (PBL), Hasil Belajar Kognitif, Biologi

\begin{abstract}
Cognitive learning results are one of the skills needed in a learning on the 21st Century in Biology learning. Empowerment of thinking and metacognitive skills needs to be done so that students become independent learners. This PBL strategy in learning is expected to help students to improve the ability of students' cognitive learning outcomes in Biology learning. This study aims to determine the improvement of cognitive learning outcomes of students taught with PBL strategies. The results showed that PBL strategies can improve students' cognitive learning outcomes in different abilities. Improvement of Cognitive Learning Outcomes of students in PBL strategies is $65.52 \%$ and conventional is $53.41 \%$.
\end{abstract}

Keywords: Problem Based Learning (PBL), Cognitve learning result, Biology

\section{PENDAHULUAN}

Pembelajaran abad ke 21 siswa harus memiliki keterampilan agar dapat bersaing di era globalisasi. Greenstein (2012) menyatakan bahwa keterampilan pembelajaran abad 21 antara lain: literasi era digital, berpikir inventive, produkstivitas, informasi dan komunikasi. Dalam mewujudkan masyarakat Indonesia yang memiliki daya saing dan inovatif, produk pendidikan harus memadai baik dari segi kuantitas maupun kualitas.

Salah satu penentu kualitas pendidikan adalah keberhasilan pendidikan pada sekolah dasar. Strategi, model atau pola pembelajaran merupakan aspek penting dalam proses pendidikan. Pengalaman belajar yang diperoleh siswa selama pembelajaran berlangsung sangat berperan dalam pembentukan kemampuan dan menentukan kualitas dari pembelajaran. Oleh karena itu, guru memiliki tanggung jawab membentuk pengalaman belajar siswa salah satunya melalui penggunaan strategi pembelajaran yang tepat karena pembelajaran yang menarik tidak cukup hanya dengan strategi pembelajaran konvensional.

Hasil observasi lainya menujukkan bahwa nilai rata-rata hasil belajar kognitif SMA di Deli Serdang sebesar 6.8 dan masih tergolong rendah. Rendahnya hasil belajar kognitif dalam pembelajaran IPA juga diduga disebabkan oleh faktor: (1) masih banyaknya permasalahanpermasalahan pembelajaran khususnya materi pembelajaran biologi dibangku sekolah sebelumnya yang belum terpecahkan; (2)siswa kurang memberdayakan keterampilan berpikir dan metakognisinya; (3) minat baca siswa terhadap materi pembelajaran untuk menyiapkan diri mengikuti pembelajaran selanjutnya masih sangat rendah, sehingga pengetahuan awal siswa pada saat pembelajaran berlangsung masih kurang. Yamin (2008) mengemukakan bahwa peserta didik harus memiliki pengetahuan awal yang akan mereka jadikan dasar untuk membangun pengetahuan selanjutnya. 
JURNAL BIOLOKUS Vol.1 (2)

Strategi pembelajaran yang dianggap tepat untuk diterapkan adalah strategi yang berlandaskan pada pendekatan konstruktivistik seperti strategi Problem Based Learning (PBL). PBL didasari bahwa belajar bukan hanya proses menghafal konsep atau fakta tetapi proses interaksi antara individu dengan lingkungannya. PBL juga dapat mengembangkan keterampilan yang diperlukan di era pengetahuan (Duch dkk., 2001; dan Tan, 2003) karena dapat mengembangkan kemampuan berpikir tingkat tinggi seperti berpikir kritis, pemecahan masalah, menemukan dan menggunakan sumber-sumber belajar, pembelajaran mandiri,mengembangkan kemampuan bekerja kooperatif, dan belajar sepanjang hayat (Steck dkk., 2012).

Pola pembelajaran biologi di Deli Serdang masih berorientasi pada hasil belajar kognitif. Berdasarkan rasionalitas kelebihan PBL serta belum adanya data tentang menigkatkan kemampuan metakognitif dan kognitif siswa SD maka perlu dilakukan penelitian tentang "Peningkatan Keterampilan Hasil belajar Kognitif Siswa dengan Menggunakan Strategi Pembelajaran Problem Based Learning (PBL) pada Pembelajaran Biologi di Kabupaten Deli Serdang”.

\section{METODE PENELITIAN}

Penelitian ini dilakukan di Kabupaten Deli Serdang. Metode penelitian yang digunakan adalah kuasi eksperimen $2 \times 2$ non faktorial equivalen grup desain. Desain penelitian yang digunakan dalam penelitian ini adalah pretest-postest nonequivalent control group design pola faktorial $2 \times 2$ seperti ditunjukkan pada Tabel 1 berikut ini :

Tabel 1Denah Penelitian Eksperimen Faktorial 2x2

\begin{tabular}{ccc} 
Kemampuan & \multicolumn{2}{c}{ Strategi Pembelajaran (S) } \\
\cline { 2 - 3 } Akademik & PBL(S1) & Konvensional(S2) \\
\hline Atas (K1) & S1K1 & S2K1 \\
\hline Bawah (K2) & S1K2 & S2K2 \\
Keterangan: & & \\
S = Strategi Pembelajaran & \\
K = Kemampuan Akademik &
\end{tabular}

(Sumber: Ary dkk.,1982; Sukardi, 2008; Sugiyono, 2009).

Prosedur pelaksanaan perlakuan strategi pembelajaran berdasarkan rancangan penelitian ditunjukkan pada Tabel 2 berikut :
Tabel 2. Kelas Perlakuan Berdasarkan Variabel

\begin{tabular}{ccc} 
Pretest & Perlakuan & Postest \\
\hline 01 & S1K1 & 02 \\
\hline 03 & S2K1 & 04 \\
\hline 05 & S1K2 & 06 \\
\hline 07 & S2K2 & 08
\end{tabular}

\section{Keterangan:}

$\mathrm{S} 1$ : Kelas strategiPBL

S2 : Kelas strategi pembelajaran konvensional

$\mathrm{K} 1$ : Kemampuan akademik atas

K2 : Kemampuan akademik bawah

01, 03, 05, 07 : Skor prettest

02, 04, 06, 08 : Skor posttest

\section{Teknik Pengumpulan Data}

Pengumpulan data penelitian ini menggunakan instrumen hasil belajar kognitif biologi siswa. Tes ini berbentuk essay dan dikembangkan sesuai dengan tingkatan taksonomi Bloom yang telah direvisi oleh Anderson \& Krathwohl (2001) Tes ini digunakan untuk mengukur hasil belajar kognitif. Sebelum tes digunakan terlebih dahulu dilakukan analisis validitas meliputi validasi isi, validasi konstruk, dan validasi empiris serta ditentukan nilai reliabilitasnya.

\section{Teknik Analisis Data}

$\begin{array}{crrr}\text { Data } & \text { penelitian } & \text { dianalisis } & \text { dengan } \\ \text { menggunakan } & \text { statistik } & \text { deskriptif } & \text { untuk }\end{array}$ menunjukkan deskripsi atau profil, hasil belajar kognitifnya. Nilai statistik deksriptif meliputi ratarata, simpangan baku, rerata tertinggi, rerata terendah, dan persentase perubahan pretest dengan posttest. Selain itu data skor variabel terikat ditampilkan dalam bentuk grafik. Data dianalisis dengan menggunakan program SPSS 20.0 for Windows.

\section{HASIL}

Hasil belajar kognitif siswa diukur sebelum dan setelah perkuliahan. Selanjutnya, data dianalisis dengan statistik deskriptif untuk mengetahui rerata dan persentase perubahan nilai hasil belajar kognitif. Data hasil penelitian terkait rerata nilai dan persentase perubahan nilai pretest-posttest hasil belajar kognitif pada setiap strategi pembelajaran menurut kemampuan akademik ditunjukkan pada Tabel 3 dan Gambar 1 berikut : 
JURNAL BIOLOKUS Vol.1 (2)

Tabel 3. Rerata Nilai dan Persentase Perubahan Nilai Pretest-Posttest Hasil Belajar Kognitif pada Setiap Strategi Pembelajaran menurut Kemampuan Akademik

\begin{tabular}{|c|c|c|c|c|c|c|}
\hline \multirow{2}{*}{ No } & \multirow{2}{*}{$\begin{array}{c}\text { Strategi } \\
\text { Pembelajaran }\end{array}$} & \multirow{2}{*}{$\begin{array}{c}\text { Kemampuan } \\
\text { Akademik }\end{array}$} & \multicolumn{2}{|c|}{ Rerata } & \multirow{2}{*}{$\begin{array}{c}\text { Perubahan } \\
\text { (\%) }\end{array}$} & \multirow{2}{*}{ Keterangan } \\
\hline & & & Pre test & Post test & & \\
\hline \multirow{3}{*}{1} & \multirow{3}{*}{$P B L$} & KA Atas & 23.76 & 58.66 & 59.49 & Meningkat \\
\hline & & KA Bawah & 14.09 & 51.13 & 72.45 & Meningkat \\
\hline & & Total & 18.93 & 54.89 & 65.52 & Meningkat \\
\hline \multirow{3}{*}{2} & \multirow{3}{*}{ Konv } & KA Atas & 29.13 & 54.29 & 46.34 & Meningkat \\
\hline & & KA Bawah & 13.13 & 36.41 & 63.94 & Meningkat \\
\hline & & Total & 21.13 & 45.35 & 53.41 & Meningkat \\
\hline \multirow{2}{*}{\multicolumn{2}{|c|}{ Total }} & KA Atas & 21.13 & 58.12 & 63.64 & Meningkat \\
\hline & & KA Bawah & 12.14 & 46.46 & 73.86 & Meningkat \\
\hline
\end{tabular}

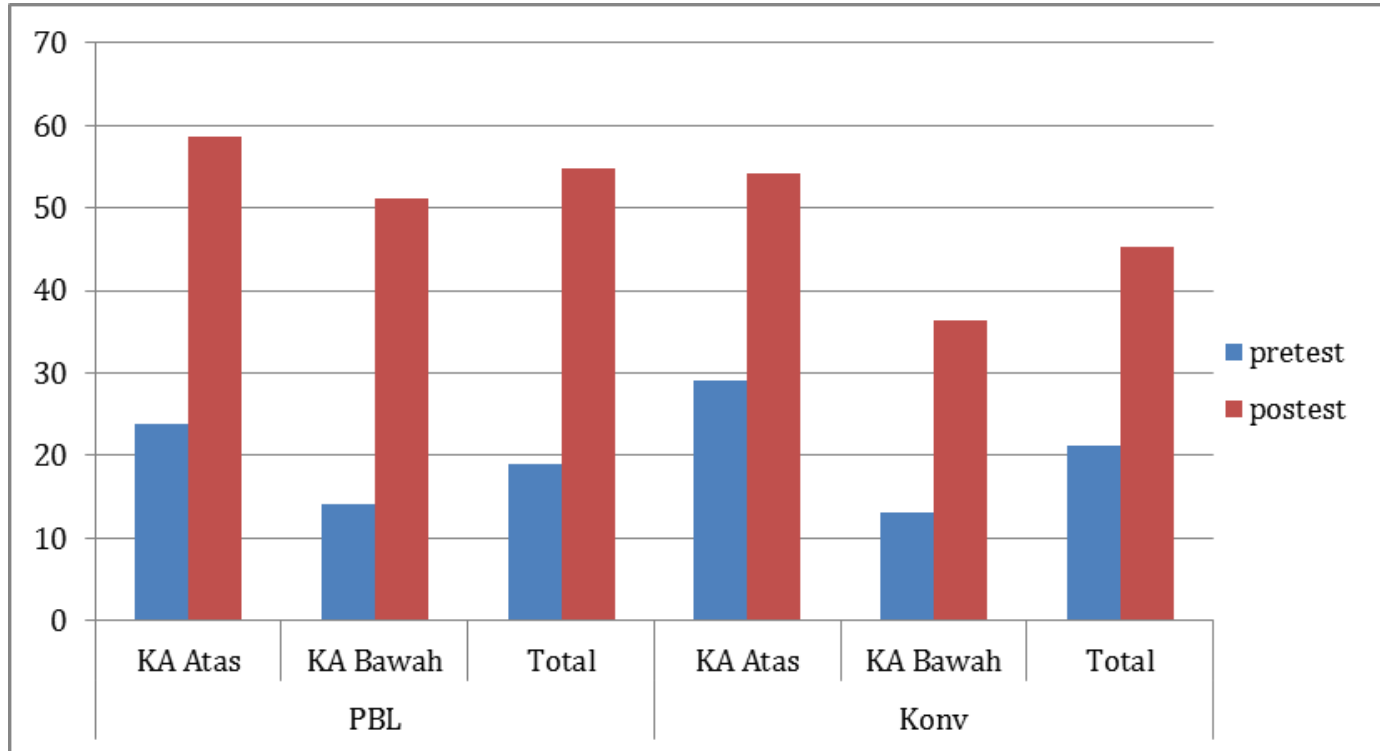

Gambar 1. Rerata Nilai Pretest-Postest Hasil Belajar Kognitif pada Setiap Strategi Pembelajaran Menurut Kemampuan Akademik.

\section{PEMBAHASAN}

Hasil penelitian menunjukkan adanya perbedaan hasil belajar kognitif siswa yang diajar dengan strategi PBL dan pembelajaran konvensional. Dimana, hasil belajar kognitif tertinggi terdapat pada mahasiswa yang diajar dengan strategi PBL. Hal yang sama, terkait dengan hasil belajar kognitif dipengaruhi oleh strategi pembelajaran dilaporkan oleh Arnyana (2004), Paidi (2008), Danial (2009), Bahri (2010), dan Muhiddin (2012). Hasil penelitian di atas sejalan dengan hasil uji anakova terhadap keterampilan metakognitif yang diukur dengan menggunakan rubrik. Hal ini menunjukkan bahwa ketika keterampilan metakognitif mahasiswa diberdayakan selama proses pembelajaran, maka akan memberikan dampak yang positif terhadap peningkatan hasil belajarnya karena mahasiswa telah terlatih menjadi pebelajar yang mandiri. Hasil ini juga akan didukung oleh pembahasan berikutnya terkait analisis korelasi antara keterampilan metakognitif dengan hasil belajar kognitif.

Adanya peningkatan hasil belajar kognitif mahasiswa yang diajar dengan menggunakan strategi PBL semakin mempertegas bahwa potensi strategi PBL dalam meningkatkan hasil belajar kognitif mahasiswa akan dimaksimalkan dalam pembelajaran. Hal ini tidak terlepas dari kerja kolaboratif di dalam tahapan pembelajaran ini. Sanjaya (2008) mengemukakan bahwa strategi pembelajaran kooperatif dapat meningkatkan prestasi akademik. 
JURNAL BIOLOKUS Vol.1 (2)

Adanya pola kerja individu dan kelompok dalam strategi PBL menyebabkan tanggung jawab individu dan kerjasama antar anggota kelompok terbentuk. Pola kerja sama dan diskusi ketika mencari solusi tentang permasalahan yang telah dimunculkan oleh masing-masing anggota kelompok, pada saat masing-masing individu bergabung dalam kelompoknya, menyebabkan tanggung jawab individu terbentuk untuk menguasai materi perkuliahan khususnya permasalahan dan solusi yang telah dimunculkan terkait materi perkuliahan. Hal ini berarti ada kerja tim dalam menyelesaikan masalah pada saat diskusi kelompok. Terkait dengan fungsi tim dalam pembelajaran kolaboratif, dikemukakan oleh Slavin (2010) bahwa fungsi tim adalah memberi dukungan kinerja akademik (penguasaan materi pelajaran) bagi anggotanya. Demikian juga dengan pernyataan Arends (2008) bahwa peserta didik dalam tim sangat membantu anggota dalam kinerja akademik dengan berbagai prosedur kooperatif. Hal ini pula menunjukkan bahwa dalam kelompok yang dibentuk ada saling ketergantungan positif antara sesama anggota kelompok dalam menguasai permasalahan dan solusi atas permasalahan tersebut.

Adanya perbedaan hasil belajar kognitif mahasiswa berkemampuan akademik atas dan bawah tidak terlepas dari skor metakognitif yang juga berbeda antara keduanya. Hasil penelitian ini sejalan dengan penelitian Antika (2013) Malahayati (2011), Muhfahroyin (2009), dan Santoso (2007) yang menunjukkan adanya pengaruh kemampuan akademik terhadap hasil belajar kognitif. Corebima (2005) menyatakan atas dasar berbagai temuan penelitian terungkap bahwa peserta didik dengan kemampuan akademik tinggi dapat mencapai pemahaman konsep yang lebih tinggi dibandingkan peserta didik berkemampuan akademik rendah. Bagi mereka yang tingkat penalarannya lebih tinggi, mampu menguji hipotesis keilmuan maupun mengidentifikasi variabel tergantung, serta lebih mampu menganalisis data. Sejalan dengan itu, Primartadi (2013) menjelaskan bahwa peserta didik yang mempunyai kemampuan potensi akademik tinggi cenderung lebih aktif dalam berdiskusi sehingga lebih memiliki wawasan yang lebih luas dan mampu membangun suasana yang kondusif dan membuat berjalanya diskusi lebih maksimal. Keaktifan tersebut akan berdampak pada hasil, pengetahuan, dan pengalaman belajar yang didapatkan.

Faktor lain yang menjadipenyebab terjadinya perbedaan hasil belajar antara mahasiswa berkemampuan akademik atas dengan berkemampuan akademik bawah adalah intelegensi. Hal ini sejalan dengan pendapat Hamalik (2004) yang menyatakan bahwa faktor intelegensi merupakan salah satu faktor yang efektif mempengaruhi keberhasilan belajar. Sehingga, mahasiswa yang memiliki kemampuan akademik awal dengan intelegensi yang lebih tingggi cenderung memiliki hasil belajar yang tinggi pula bila dibandingkan dengan mahasiswa dengan kemampuan akademik bawah. Hal ini diperkuat oleh Ivie (1998) yang mengemukakan bahwa peserta didik dengan kemampuan akademik tinggi akan mencapai kemampuan berpikir yang lebih baik dari yang berkemampuan rendah. Hal tersebut dapat disebabkan karena kemampuan berpikir berguna sebagai modal dalam pemecahan masalah dan lebih lanjut dapat mempengaruhi tingkat intelektual peserta didik.

\section{KESIMPULAN}

Berdasarkan hasil penelitian yang telah dilakukan dapat diambil kesimpulan sebagai berikut: Terdapat peningkatan hasil belajar kognitif siswa yang diajar dengan strategi PBL sebesar $65.52 \%$ pada mata pembelajaran biologi; strategi PBL dapat meningkatkan hasil belajar kognitif siswa.

\section{REFERENSI}

Ackay, B. 2009. PBL in Science Education. Journal of Turkish Science Education, 6 (1), 26 -36.

Akinoglu, Orhan dan R. O. Tandogan. 2007. The Effects of Problem-Based Active Learning in Science Education on Students' Academic Achievement, Attitude and Concept Learning. Eurasia Journal of Mathematic, Science \& Technology Education, 2007, 3(1), 71-81.

Anderson, O.W. and Krathwohl, D.R., 2001. A Taxonomy for Learning, Teaching, and Assessing (A Revision of Bloom's Taxonomy of Educational Objectives). New York: Addision Wesley Longman, Inc. 
Anderson, N. J. 1991. Individual differences in strategy use in second language reading and testing. Modern Language Journal 75 (4): 460-72.

Antika, L.T. 2013. Perbandingan Keterampilan Metakognitif, Hasil Belajar Biologi, dan Retensi Antara Siswa Berkemampuan Akademik Tinggi dan Rendah Kelas X SMA di Malang melalui Strategi Problem Based Learning (PBL). Skripsi tidak diterbitkan. Malang: Jurusan Biologi FMIPA Universitas Negeri Malang.

Antika, L. T. 2015. Hubungan anatara Minat Baca, Keeterampilan Metakognitif, dan Keterampilan Berpikir Kritis dengan Hasil Belajar Biologi Berbasis Reading-Concept Map-Think Pair Share (TPS). Tesis tidak diterbitkan. Malang: Universitas Negeri Malang.

Ardila, C., Corebima, A. D., \& Zubaidah, S. 2013. Hubungan Keterampilan Metakognitif Terhadap Hasil Belajar Biologi dan Retensi Siswa Kelas X dengan Penerapan Strategi Permberdayan Berpikir Melalui Pertanyaan (PBMP) di SMAN 9 Malang. Jurnal Online Universitas Negeri Malang, Indonesia. (http://jurnal-online.um.ac.id/data/artikel).

Ary, D., Jacobs, L.C, dan Razavieh, A. 1982. Pengantar Penelitian dalam Pendidikan. Terjemahan oleh Arief Furchan. Surabaya: Usaha Nasional.

Bloom, B. S. 1981. Taxonomy of Educational Objectives. New York : Longman Inc.

Brown, A. L. dan DeLoache, J. S. 1978. Skills, Plans, and Self-regulation. In $R$. S. Siegel (ed.), Childrens Thinking: What Develops. Hillsdele, N. J. Erlbaum.

Corebima, A.D. 2005a. Pemberdayaan Berpikir Siswa pada Pembelajaran Biologi: Satu Penggalakan Penelitian Payung di Jurusan Biologi UM. Makalah disajikan dalam Seminar Nasional Biologi dan Pembelajarannya, Malang, 3 Desember 2005.

Corebima, A.D. 2005b. Pengukuran Kemampuan Berpikir pada Pembelajaran Biologi. Makalah disajikan dalam Seminar Dies ke-41 Universitas Negeri Yogyakarta: Hasil Penelitian Tentang Evaluasi Hasil Belajar Serta Pengelolaannya, di Yogyakarta: 14-15 Mei 2005.
Corebima. A. D. 2006a. Strategi Pembelajaran yang Memberdayakan Kemampuan Berpikir dan Pemahaman Konsep Siswa Berpotensi Akademik Rendah. Makalah disajikan pada The International Conference on Mathemathics and Science Education di UNJ Jakarta pada tanggal 29-30 Nopember 2006.

Corebima, A. D. 2006b. Metakognisi: Suatu Ringkasan Kajian. Makalah Disajikan dalam Pelatihan Metakognitif pada Pembelajaran Biologi untuk Guru-guru Biologi SMA, Lembaga Pengabdian kepada Masyarakat (LPKM) UNPAR, Palangakaraya, 23 Agustus 2006.

Corebima, A.D. 2007a. Learning Strategies Having Bigger Potency To Empower Thinking Skill and Concept Gaining of Lower Academic Students. Proceedings of Redesigning Pedagogy Conference, Nanyang, May 28-30 2007.

Corebima, A.D. 2007b. Metakognisi: Suatu Ringkasan Kajian. Makalah disampaikan pada Diklat Guru Mata Pelajaran Biologi di Yogyakarta.

Corebima, A.D. 2008. Rubrik Keterampilan Metakognisi yang Terintegrasi dengan Tes Essay, Rubrik MAD. Malang.

Corebima, A.D. 2009a. Jadikan Peserta Didik Pebelajar Mandiri. Makalah. Disampaikan pada Seminar di UNM pada tanggal 19 Desember 2009.

Corebima, A.D. 2009b. Pengalaman Berupaya Menjadi Guru Profesional. Pidato Pengukuhan Guru Besar dalam Bidang Genetika pada Fakultas Matematika dan Ilmu Pengetahuan Alam, disampaikan pada Sidang Terbuka Senat Universitas Negeri Malang pada tanggal 30 Juli 2009.

Corebima, A.D. 2009c. Metacognitive Skill Measurment Integrated in Achievement Test. Makalah disajikan pada The Third CosMED di Penang, Malaysia.

Corebima, A.D. 2010. Berdayakan Keterampilan Berpikir Selama Pembelajaran Sains Demi Masa Depan Kita. Makalah Disampaikan pada Seminar Nasional Sains di Unesa pada Tanggal 16 Januari 2010.

Corebima, A. D., \& Bahri, A. 2011a. Reading, Questioning, and Answering (RQA): A New Learning Strategy to Enhance Student 
JURNAL BIOLOKUS Vol.1 (2)

Metacognitive Skill and Concept Gaining. Paper presented at International Symposium at Nanyang Technology University, Singapura. 2011.

Corebima, A.D. 2011b. The Validation of Metacognitive Skill Measurement Integrated in Achievement Test. Makalah disampaikan pada Seminar Internasional Redesigning Pedagogy di NIE (NTU), Singapura, Juni 2011.

Corebima, A.D. 2011c. Assesmen Pembelajaran. Makalah disampaikan pada Seminar Nasional Peningkatan Kompetensi Pedagogik melalui Penguasaan Assesmen Metakognisi dan Keterampilan Berpikir di UNM tanggal 17 Desember 2011.

Danial, M. 2010. Pengaruh Strategi Pembelajaran PBL dan GI terhadap Metakognisi dan Penguasaan Konsep Kimia Dasar Siswa Jurusan Biologi FMIPA UNM. Disertasi tidak diterbitkan. Malang: PPS UM.

Fauziyah, D. R., Corebima, A. D.,\& Zubaidah, S. 2013. Hubungan Keterampilan Metakognitif Terhadap Hasil Belajar Biologi dan Retensi Siswa Kelas $X$ dengan Penerapan Strategi Pembelajaran Think Pair Sharedi SMA Negeri 6 Malang. Jurnal Online Universitas Negeri Malang, Indonesia. (http://jurnalonline.um.ac.id/data/artikel ).

Flavell, J. H. 1976. Metacognitive Aspect of Problem Solving. In L. B. Resnick (Ed.), The Nature of Intelligence (pp.231-236). Hillsdale, NJ: Erlbaum Association.

Flavell, J. H. 1979. Cognitive Development: Children's Knowledge about the Mind. Annual Review of Psychology. Vol. 50: 21-45.

Hmelo-Silver, C. E. 2004. Problem-Based Learning: What and How Do Students Learn? Educational Psychology Review. Vol. 16 (3): 235-266.

Sugiyono. 2009. Metode Penelitian Pendidikan: Pendekatan Kuantitatif, Kualitatif dan R \& D. Bandung: Alfabeta.

Sukardi. 2008. Metode Penelitian Pendidikan: Kompetensi dan Praktiknya. Yogyakarta: Bumi Aksara.

Veenman, M.V.J., 2006. Metacognition and Learning: Conceptual and Methodological Considerations. Recieved: 08 December 2005. Business Media, Inc. 2006. (www://springerlink.com,

diakses 2 Oktober 2009).

Warouw, Z. W. M. 2009. Pengaruh Pembelajaran Metakognitif dengan Strategi Cooperative Script, dan Reciprocal Teaching pada Kemampuan Akademik Berbeda Terhadap Kemampuan dan Keterampilan Metakognitif, Berpikir Kritis, Hasil Belajar Biologi Siswa, serta Retensinya di SMP Negeri Manado. Disertasi tidak diterbitkan. Malang: PPS Universitas Negeri Malang. 